\title{
A VALORIZAÇÃO DA CULTURA LOCAL COMUNICADA POR MEIO DE UM PRODUTO TÊXTIL
}

\section{Nercy Gularte, graduanda em Design de Moda (ASSEVIM); Michela Cristiane França Goulart, M.Sc (UFSC).}

\section{INTRODUÇÃO}

A cultura é um dos maiores legados do homem e a indústria têxtil por sua vez é um dos segmentos que reproduz esta cultura e consegue perpetuá-la. O presente artigo tem como objetivo buscar a valorização da cultura local comunicada por meio do desenvolvimento de um produto têxtil. O produto têxtil foi desenvolvido para a disciplina de materiais e tecnologia têxtil e proposto como trabalho de conclusão de curso, cujo tema era utilizar artistas brusquenses como inspiração para criar um tecido sendo escolhida as obras da ilustradora Márcia Cardeal para o desenvolvimento de um tecido jacquard, onde denominou-se Projeto Lupa-lupa.

Para tanto, fundamentou-se nos conceitos de cultura, modernidade e comunicação afim de compreender como estes estão interligados. Rodrigues (2015) cita que a cultura, do ponto de vista da sociologia, se ocupa em entender aquilo que o ser humano aprende em seu contato social e adquire ao longo de sua convivência. Em poucas palavras, a cultura está relacionada ao tempo. Por sua vez, a modernidade pode ser caracterizada pela realidade social, cultural e econômica vigente no mundo. E ambas estão vinculadas pela comunicação que é uma das ações humanas utilizadas em todos os tempos e na qual são obtidas as informações, sejam visuais, verbais ou escritas (MARQUES, 2008).

\section{PROJETO LUPA-LUPA}

O projeto Lupa-Lupa consistiu em desenvolver um tecido para forração, sendo este fabricado por meio de tecelagem usando a técnica jacquard, usado para forração de sofás, colchões, almofadas, paredes e inúmeros tipos de decorações, tendo como estrutura, composição, tamanho e gramatura: poliéster, largura de 1,45m e peso $250 \mathrm{~g} / \mathrm{m}^{2}$. Com base na ilustração do livro "Um cavalo para Eduardo" foi desenhado uma releitura da obra, conforme Figura 1.

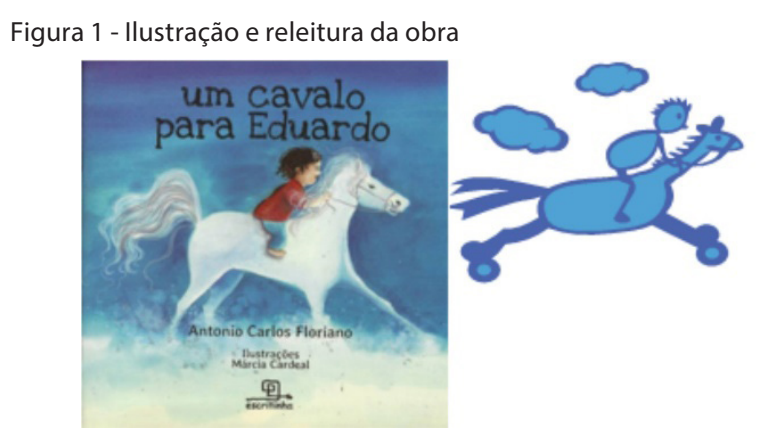

Fonte: ELIANE DEBUS (2013); Autoria própria (2015).

A estrutura da releitura foi desenvolvida com a técnica de Rapport que é um modo de repetição de um módulo com encaixes projetados para alcançar um resultado específico (ROCHA, 2014). Como resultado o rapport feito com a releitura da obra foi aplicado para simulação do resultado final (Figura 2).

Figura 2 - Rapport e aplicação da releitura
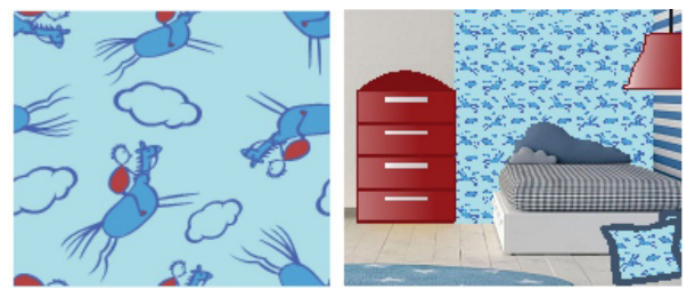

Fonte: Autoria própria (2015).

Como resultados do projeto foi possível verificar que um produto têxtil pode comunicar valores da cultura local e que a cultura pode ter aspectos tangíveis, nos quais objetos ou símbolos fazem parte do seu contexto e os intangíveis que são considerados as ideias, normas que regulam o comportamento, formas de religiosidade.

\section{REFERÊNCIAS}

ELIANE DEBUS (Santa Catarina). Literatura Infantil e Juvenil produzida em Santa Catarina: Um cavalo para Eduardo. 2013. Disponível em: <http://literaturainfantiljuvenilsc.ufsc.br/obras/um-cavalo-para-eduardo>. Acesso em: 06 fev. 2016. 
MARQUES, P.J.N. O Impacto da Cultura no Comportamento do Consumidor: uma abordagem geral. Disponível em: <https://estudogeral.sib.uc.pt/bitstream/10316/27344/1/o\%20impacto\%20da\%20cultura\%20 no\%20comportamento $\% 20$ do\%20consumidor.pdf> Acesso em: 14 out. 2015.

ROCHA, L. O que é Rapport? Disponível em: <https:// metapix.com.br/artigo/2014/05/26/o-que-e-rapport/ > Acesso em: 29 nov. 2015.

RODRIGUES, O. L. de. Cultura. Disponível em:<http:// mundoeducacao.bol.uol.com.br/sociologia/conceito-cultura.htm > Acesso em 28 out. 2015. 